\title{
A 20 YEARS' EXPERIENCE ON GRANULOSA CELL TUMOUR
}

\author{
P. Jovita M. Martin'1, Kalaichelvi K², Lakshminarasimhan ${ }^{3}$, Ramkumar $^{4}$, Dheenadhayalan 5 \\ ${ }_{1}^{1}$ Assistant Professor, Department of Medical Oncology, SRMC, Chennai, Tamilnadu, India. \\ 2Professor, Department of Medical Oncology, Madras Medical College, Chennai, Tamilnadu, India. \\ 3 Professor, Department of Medical Oncology, SRMC, Chennai, Tamilnadu, India. \\ ${ }^{4}$ Associate Professor, Department of Medical Oncology, IOG, Egmore, Chennai, Tamilnadu, India. \\ ${ }^{5}$ Resident, Department of Medical Oncology, Madras Medical College, Chennai, Tamilnadu, India.
}

\begin{abstract}
BACKGROUND
ABSTRACT

The prognostic factors and the recurrent nature of Granulosa cell tumour is unclear. Chemotherapy has a compelling role in locally advanced cases, inoperable cases and metastatic cases. This retrospective study results elucidate the need for chemotherapy in advanced cases which then translates to a better overall survival benefit, increased disease free survival and delay in progression. The prognostic factors and the recurrent nature of Granulosa cell tumour is unclear and unpredictable added to the fact that these tumours are rare and have an indolent course. There is only a scarce data on the optimum treatment for this group of patient.

The aim of this study was to pursue the clinico-pathological features and prognostic factors for the recurrence patterns and the optimal management of these cases.
\end{abstract}

\section{MATERIALS AND METHODS}

This is a descriptive study with secondary data from records. A retrospective multi-institutional review of patients with GCTs of the ovary treated or referred were analysed. Surgical outcome, pathological details, chemotherapy details, follow-up details, relapse pattern and the treatment of the relapse disease were analysed. Kaplan-Meier survival analysis was used to determine the prognostic and predictive markers for survival.

\section{RESULTS}

This is an analysis of the survival rate and the treatment results of Granulosa cell tumour between 1995 and 2015 over a period of 20 years. We have analysed the results of 126 patients, of which 53 patients (42\%) were premenopausal and 73 patients (58\%) were postmenopausal. Out of the 126 patients 84 patients had complete surgical staging which constitutes transabdominal hysterectomy and bilateral salpingo-oophorectomy and a staging laparotomy, 35 patients had incomplete or suboptimal surgery, 7 patients had fertility sparing operation. The 67 patients who had complete surgery and early stage disease with no risk factors were on observation. These patients have not had relapse. A dataset of 34 relapsed granulosa cell tumour patients were analysed. Out of these, 19 patients have survived cancer. Out of 34 cases, 10 patients had complete surgery and 15 patients had incomplete surgery including fertility preserving surgery. Kaplan-Meier survival analysis results show that cancer was cured by complete surgery followed in chemotherapy wherever high-risk factors were present, whereas the survival rate drastically declined in the cases of incomplete surgery without adjuvant chemotherapy. For patient's stage of cancer size of the tumour, type of surgery done, tumour spill, histopathology and chemotherapy in positive high-risk parameters have relatively more effect on survival chance.

\section{CONCLUSION}

Granulosa cell tumours are known for their rarity. Chemotherapy has a compelling role in locally advanced cases, inoperable cases, metastatic cases, in cases with tumour spill or rupture, certain histopathological variants (such as juvenile granulosa cell tumour, yolk sac tumour) and tumours $>9 \mathrm{~cm}$. Other factors which do contribute to the prognosis would be age at diagnosis, nuclear atypia, mitotic index, surgical method and presence of residual disease after initial surgery.

\section{KEY WORDS}

Granulosa Cell Tumour, Recurrence of Granulosa Cell Tumour.

HOW TO CITE THIS ARTICLE: Martin PJM, Kalaichelvi K, Lakshminarasimhan, et al. A 20 years' experience on granulosa cell tumour. J. Evolution Med. Dent. Sci. 2018;7(26):3004-3012, DOI: 10.14260/jemds/2018/676

\section{BACKGROUND}

Ovarian sex cord stromal cells are known for their rarity comprising of $2-3 \%$ of all primary ovarian cancers.

'Financial or Other Competing Interest': None.

Submission 29-05-2018, Peer Review 10-06-2018,

Acceptance 13-06-2018, Published 25-06-2018.

Corresponding Author:

P. Jovita M. Martin,

AG Alsa Deer Park,

\#108, Velechery Main Road,

Huindy, Chennai-32,

Tamilnadu, India.

E-mail: jovimartin4@gmail.com

DOI: $10.14260 /$ jemds $/ 2018 / 676$
They are known for their heterogeneity as well. From benign to malignant subtypes, there are several varieties known. They develop from the proliferating cells which produce cells to support and surround oocytes, which includes the cells that produce ovarian hormones. The different types of sex cord stromal tumours include fibromathecoma, granulosa cell tumour (adult and juvenile, which differentiates into female characteristics), Sertoli-Leydig cell tumour (which differentiates into male characteristics). Granulosa cell tumour have the most common malignant potential among the sex cord stromal cell tumours as described by Rokitansky in $1855 .^{1}$

The adult subtype is often seen in the middle aged and old aged women with a median age of 50 - 54 years. The juvenile 
subtype comprises of only $5 \%$ of the total sex cord stromal tumours, typically develop before puberty, common in children and young women being highly proliferative but with a lower risk of recurrence. ${ }^{2}$

Malignant sex cord tumour cells are diagnosed at an earlier stage and are considered to be low-grade malignancies compared to the primary ovarian cancers. Granulosa cell tumour present with features of hyperoestrogenism such as abnormal vaginal bleeding and precocious puberty. ${ }^{3}$

Complete surgery is the main stay of the management in early stages. Adjuvant platinum-based chemo is indicated in advanced stages. Though granulosa cell tumours have favourable prognosis, late relapses are known to occur due to the indolent nature of the disease. Advanced disease has a poor prognosis with 5-year survival rate of $0-20 \%$ in comparison to epithelial ovarian cancer. ${ }^{4}$

The most common prognostic factors known in granulosa tumours are age, tumour size, tumour stage, bilaterality, postop residual tumour status and high mitotic index.5-15

The prognostic factors and the recurrent nature is unclear and unpredictable added to the fact that these tumours are rare and have an indolent course. There is only a scarce data on the optimum treatment for this group of patients. The present study is conducted to pursue the clinico-pathological features and prognostic factors for the recurrence patterns and the optimal management of these cases.

\section{MATERIALS AND METHODS}

This is a descriptive study with secondary data from records. All cases of histologically proven and treated patients between 1993 and 2015 in the Department of Obstetrics and Gynaecology were analysed retrospectively with the medical records. Information on the patient's characteristics, clinical presentation, International Federation of Gynaecology and Obstetrics Staging (FIGO), surgical details, adjuvant details, recurrences, management of recurrences and follow-up until 2015 were analysed.

Size of the tumour was ascertained by preoperative ultrasound or computer tomography. All patients had surgery. The complete staging laparotomy included total abdominal hysterectomy + bilateral salpingo-oophorectomy with optimal resection (RO), omentectomy, +/lymphadenectomy and multiple biopsies. All other surgeries constituted partial surgical staging. Fertility preserving surgery or fertility sparing surgery was defined as preservation of the uterus and at least one adnexa. In advanced stages, patient received chemotherapy. Other patients were put on active surveillance.
Characteristics

\begin{tabular}{|c|c|}
\hline Age & Percentage \\
\hline$<10$ & 3 \\
\hline $10-19$ & 3 \\
\hline $20-29$ & 17 \\
\hline $30-39$ & 20 \\
\hline $40-49$ & 28 \\
\hline $50-59$ & 28 \\
\hline $60-70$ & 26 \\
\hline$>70$ & 1 \\
\hline Median Age & \\
\hline
\end{tabular}

Total 126 patients- Premenopausal 58 patients and Postmenopausal 44 patients.

\begin{tabular}{|c|c|}
\hline Symptoms & N\% \\
\hline Abdominal pain & 40 \\
\hline Palpable mass & 20 \\
\hline Abdominal distension & 6 \\
\hline Precocious puberty & 2 \\
\hline Virilisation & 2 \\
\hline Mastalgia & 1 \\
\hline Menorrhagia & 33 \\
\hline Postmenopausal bleeding & 24 \\
\hline Secondary amenorrhea & 0 \\
\hline Constipation & 0 \\
\hline Urinary tract symptoms & 0 \\
\hline
\end{tabular}

\begin{tabular}{|c|c|}
\hline $\begin{array}{l}\text { Surgical Approach: Laparotomy and } \\
\text { Laparoscopy }\end{array}$ & $\begin{array}{c}126(100 \%) \\
\text { n (\%) }\end{array}$ \\
\hline $\begin{array}{l}\text { FIGO Stage } \\
\end{array}$ & $\mathrm{N}(\%)$ \\
\hline Ia & 79 \\
\hline $\mathrm{Ib}$ & 14 \\
\hline Ic & 11 \\
\hline IIa & 1 \\
\hline IIb & 1 \\
\hline IIc & 2 \\
\hline IIIa & 7 \\
\hline IIIb & 4 \\
\hline IIIc & 4 \\
\hline IV & 3 \\
\hline Surgical staging & $\mathrm{n}(\%)$ \\
\hline Complete surgical staging & 85 \\
\hline Incomplete surgical staging & 41 \\
\hline PLND & $\mathrm{n}(\%)$ \\
\hline No & 44 \\
\hline Yes & 82 \\
\hline Fertility sparing surgery & $\mathrm{n}(\%)$ \\
\hline Yes & 10 \\
\hline No & 116 \\
\hline Postoperative residual tumour & $\mathrm{n}(\%)$ \\
\hline Yes & 41 \\
\hline No & 85 \\
\hline Intraoperative tumour rupture & $\mathrm{n}(\%)$ \\
\hline Yes & 5 \\
\hline No & 121 \\
\hline
\end{tabular}




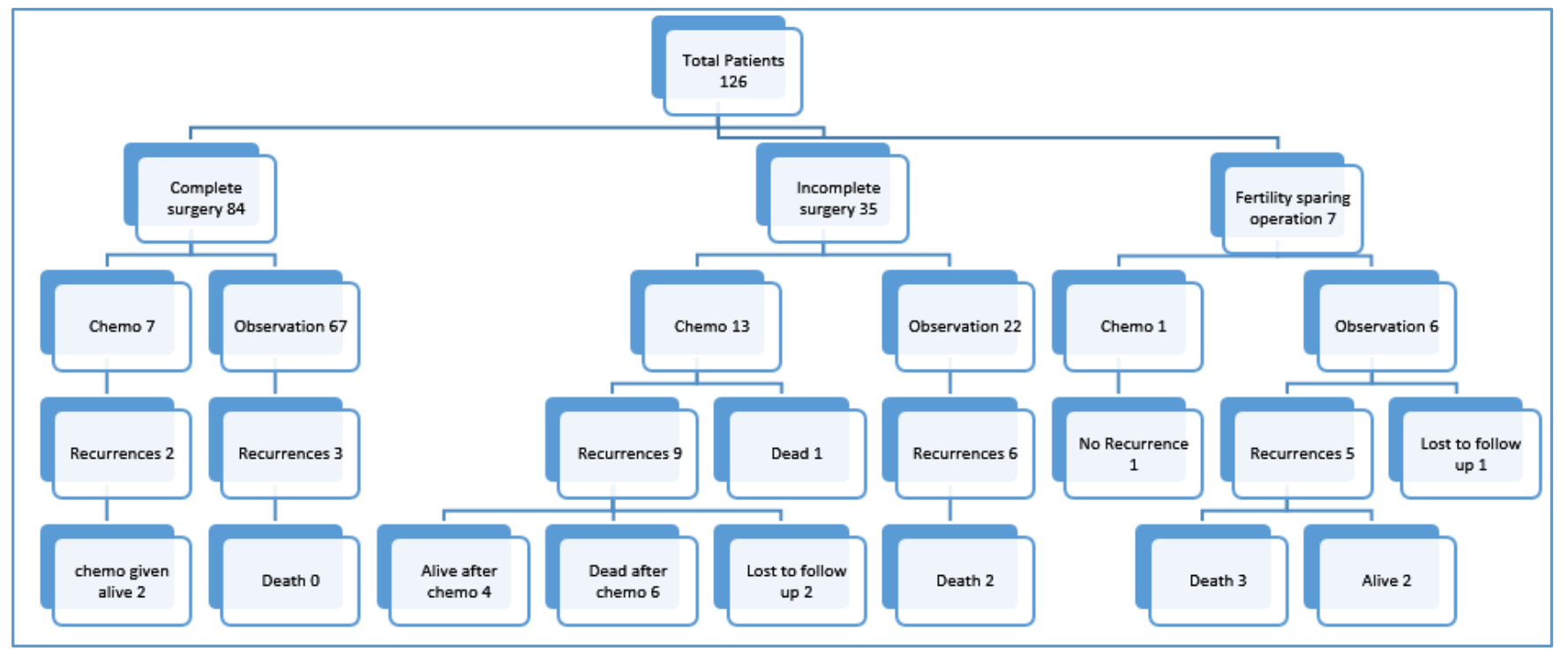

Flow Chart showing the number of patients who relapsed and their Treatment Results

Out of the 84 patients who had complete surgery, those who had chemotherapy did not show recurrence. Out of the 77 patients who were on observation, 3 patients had recurrences.

\begin{tabular}{|c|c|c|c|c|c|c|c|c|c|}
\hline 1 & 45 & IIIc AGCT & $>10 \mathrm{~cm}$ & $\begin{array}{l}\text { Incomplete } \\
\text { Surgery }\end{array}$ & 15 months & $\begin{array}{c}\text { Pelvis and } L N \text { and } \\
\text { Left adnexa }\end{array}$ & $\begin{array}{c}2 \text { lines of chemo, CDDP + } \\
\text { VCR, then CDDP + VP16 } \\
\text { oral Endoxan }\end{array}$ & $\begin{array}{c}\text { Alive with } \\
\text { disease } 90 \\
\text { months } \\
\end{array}$ & Alive \\
\hline 2 & 55 & IIIc AGCT & $12 \mathrm{~cm}$ & $\begin{array}{l}\text { Incomplete } \\
\text { Surgery }\end{array}$ & 5 months & \begin{tabular}{|c|} 
Myometrial \\
infiltration \\
present upfront, \\
relapsed in pelvis
\end{tabular} & $\begin{array}{l}2 \text { lines of chemo, CDDP + } \\
\text { VCR, then CDDP + VP16 }\end{array}$ & $\begin{array}{l}\text { Lost for follow- } \\
\text { up by } 16 \\
\text { months }\end{array}$ & LTFU \\
\hline 3 & 35 & Ic SCST & $9 \mathrm{~cm}$ & $\begin{array}{l}\text { Complete } \\
\text { Surgery }\end{array}$ & 89 months & Omentum + Pelvis & $\begin{array}{c}\text { CDDP + Ctx } 6 \text { cycles } \\
\text { chemo, then CDDP + } \\
\text { Etoposide } \\
\end{array}$ & $\begin{array}{l}123 \text { months } \\
\text { alive }\end{array}$ & Alive \\
\hline 4 & 56 & IIIc SCST & $\begin{array}{c}8.1 \times 8.1 \\
\mathrm{~cm}\end{array}$ & $\begin{array}{l}\text { Incomplete } \\
\text { Surgery }\end{array}$ & 3 months & Pelvis & $\mathrm{BEP}$ & at 3 months & Died \\
\hline 5 & 42 & Ic AGCT & $25 \mathrm{~cm}$ & $\begin{array}{l}\text { Incomplete } \\
\text { Surgery }\end{array}$ & 11 months & Pelvis & \begin{tabular}{|} 
Initially no chemo, Ctx + \\
CDDP 6 cycles, then CDDP \\
+ Etoposide $\mathrm{x} 6$ cycles
\end{tabular} & $\begin{array}{l}133 \text { months on } \\
\text { follow-up alive }\end{array}$ & Alive \\
\hline 6 & 65 & Ia AGCT & $8 \times 9$ & $\begin{array}{l}\text { Complete } \\
\text { Surgery }\end{array}$ & 12 months & Pelvis & $\begin{array}{c}\text { No initial chemo, } 4 \text { cycles } \\
\text { CDDP + CTx chemo }\end{array}$ & $\begin{array}{c}\text { Alive } 150 \\
\text { months }\end{array}$ & Alive \\
\hline 7 & 26 & IV AGCT & $20 \mathrm{~cm}$ & FSO & 25 months & Pelvis & $\begin{array}{c}\text { CDDP + Bleo + Vinb } 3 \\
\text { cycles initially PR, then } 2 \\
\text { years on Endoxan } \\
\end{array}$ & $\begin{array}{c}\text { Dead at } 8 \\
\text { months }\end{array}$ & Died \\
\hline 8 & 25 & IIIc AGCT & NA & $\begin{array}{l}\text { Incomplete } \\
\text { Surgery }\end{array}$ & 24 months & Omentum + PAN & $\begin{array}{l}\text { Initially no chemo, PEB; } \\
\text { VAC; CDDP + Ctx each } 6 \\
\text { cycles }\end{array}$ & $\begin{array}{l}\text { Alive } 132 \\
\text { months }\end{array}$ & Alive \\
\hline 9 & 42 & IV SCST & $10 \mathrm{~cm}$ & $\begin{array}{c}\text { Incomplete } \\
\text { surgery }\end{array}$ & 26 months & Liver & $\begin{array}{c}3 \text { cycles chemo initially, } \\
\text { then } 6 \text { cycles EP }\end{array}$ & $\begin{array}{c}\text { Dead at } 35 \\
\text { months }\end{array}$ & Died \\
\hline 10 & 18 & Ic SCST & $9 \mathrm{~cm}$ & FSO & $\begin{array}{c}\text { Progressed } \\
\text { at } 11 \text { months }\end{array}$ & Pelvis & 2 lines chemo & $\begin{array}{c}\text { Dead at } 23 \\
\text { months }\end{array}$ & Died \\
\hline 11 & 14 & Ia JGCT & $10 \mathrm{~cm}$ & FSO & $\begin{array}{l}\text { Progressed } \\
\text { at } 7 \text { months }\end{array}$ & Pelvis & $\mathrm{EP}$ & $\begin{array}{c}\text { Dead at } 7 \\
\text { months }\end{array}$ & Died \\
\hline 12 & 23 & $\begin{array}{l}\text { Ic androgen } \\
\text { secreting }\end{array}$ & $7 \times 9 \mathrm{~cm}$ & FSO & 8 months & Pelvis & PEB 4 cycles & $\begin{array}{c}\text { Alive } 85 \\
\text { months }\end{array}$ & Alive \\
\hline 13 & 40 & Ia AGCT & $9 \times 9 \mathrm{~cm}$ & $\begin{array}{c}\text { Complete } \\
\text { surgery }\end{array}$ & 10 months & nil & $\begin{array}{c}\text { CDDP + CT x } 6 \text { cycles } \\
\text { alone }\end{array}$ & $\begin{array}{c}\text { Alive } 87 \\
\text { months }\end{array}$ & Alive \\
\hline 14 & 44 & Ic AGCT & NA & FSO & 26 months & Pelvis & $\begin{array}{c}\text { No initial chemo, } 6 \text { cycles } \\
\text { CDDP + Ctx }\end{array}$ & $\begin{array}{l}\text { Alive } 120 \\
\text { months }\end{array}$ & Alive \\
\hline 15 & 30 & IV AGCT & NA & $\begin{array}{c}\text { Incomplete } \\
\text { surgery }\end{array}$ & Progressed & Pelvis & $\begin{array}{c}\text { CDDP + VP16 } 4 \text { cycles, } \\
\text { then } 3 \text { cycles }\end{array}$ & $\begin{array}{c}\text { Dead at 2nd } \\
\text { month }\end{array}$ & Died \\
\hline 16 & 48 & IIIa AGCT & NA & $\begin{array}{l}\text { Complete } \\
\text { surgery }\end{array}$ & $\begin{array}{l}\text { At 76th } \\
\text { month }\end{array}$ & Pelvis & $\begin{array}{c}\text { No initial chemo, } 6 \text { cycles } \\
\text { CDDP + Ctx }\end{array}$ & $\begin{array}{l}98 \text { months } \\
\text { alive }\end{array}$ & Alive \\
\hline 17 & 40 & IIIc AGCT & $\begin{array}{c}18 \times 20 \\
\mathrm{~cm}\end{array}$ & $\begin{array}{l}\text { Incomplete } \\
\text { surgery }\end{array}$ & Progressed & Omentum & 6 cycles CDDP + Ctx & 5 months dead & Died \\
\hline 18 & 60 & IIIa AGCT & NA & Complete & No relapse & nil & 6 cycles alone & 43 months & Alive \\
\hline
\end{tabular}




\begin{tabular}{|c|c|c|c|c|c|c|c|c|c|}
\hline & & & & Surgery & & & & Alive & \\
\hline 19 & 57 & Ia AGCT & $\begin{array}{c}15 \times 10 \\
\mathrm{~cm}\end{array}$ & $\begin{array}{l}\text { Complete } \\
\text { surgery }\end{array}$ & No relapse & nil & 5 cycles alone & $\begin{array}{l}72 \text { months } \\
\text { alive }\end{array}$ & Alive \\
\hline 20 & 42 & IIIc AGCT & NA & $\begin{array}{l}\text { Incomplete } \\
\text { surgery }\end{array}$ & Defaulted & Omentum, Pelvis & Defaulted & $\begin{array}{l}\text { Dead at } 3 \\
\text { months }\end{array}$ & Died \\
\hline 21 & 50 & IIIc AGCT & NA & $\begin{array}{l}\text { Complete } \\
\text { surgery }\end{array}$ & No relapse & nil & 6 cycles chemo alone & $\begin{array}{l}126 \text { months } \\
\text { Alive }\end{array}$ & Alive \\
\hline 22 & 58 & IIIC AGCT & $8 \times 8 \mathrm{~cm}$ & $\begin{array}{l}\text { Complete } \\
\text { surgery }\end{array}$ & 30th month & Pelvis & \begin{tabular}{|c|}
6 cycles chemo initially \\
post-surgery after relapse \\
CDDP + Etoposide; PVB \\
\end{tabular} & $\begin{array}{l}\text { At } 61 \text { months } \\
\text { alive }\end{array}$ & Alive \\
\hline 23 & 48 & Ic AGCT & NA & $\begin{array}{c}\text { Complete } \\
\text { surgery }\end{array}$ & 37th month & nil & 6 cycles alone & $\begin{array}{c}\text { Alive } 148 \\
\text { months }\end{array}$ & Alive \\
\hline 24 & 21 & IIIc JGCT & NA & FSO & Defaulted & Pelvis & 2 cycles & $\begin{array}{l}\text { Lost for follow- } \\
\text { up }\end{array}$ & LTFU \\
\hline 25 & 38 & IIa AGCT & $\begin{array}{c}10.6 \mathrm{x} \\
11.94 \\
\mathrm{~cm} \\
\end{array}$ & $\begin{array}{l}\text { Optimal } \\
\text { surgery }\end{array}$ & 10 months & Pelvis, Omentum & 6 cycles initially & $\begin{array}{l}83 \text { months } \\
\text { alive }\end{array}$ & Alive \\
\hline 26 & 21 & Ia AGCT & $10 \mathrm{~cm}$ & FSO & 12 months & Liver & $\begin{array}{c}\begin{array}{c}\text { CDDP + Etoposide } 6 \\
\text { cycles }\end{array} \\
\end{array}$ & $\begin{array}{l}\text { Dead at } 14 \\
\text { months }\end{array}$ & Died \\
\hline 27 & 52 & Ia AGCT & NA & $\begin{array}{c}\text { Incomplete } \\
\text { Surgery }\end{array}$ & 24 months & $\begin{array}{l}\text { Omentum and } \\
\text { PAN }\end{array}$ & $\begin{array}{c}\text { Initially no chemo, } 2 \text { lines } \\
\text { chemo }\end{array}$ & $\begin{array}{l}\text { Alive at } 140 \\
\text { months }\end{array}$ & Alive \\
\hline 28 & 55 & Ia AGCT & $6 \mathrm{~cm}$ & $\begin{array}{l}\text { Incomplete } \\
\text { surgery }\end{array}$ & 24 months & Liver & Defaulted & $\begin{array}{c}\text { Dead at } 26 \\
\text { months }\end{array}$ & Died \\
\hline 29 & 19 & Ia AGCT & $10 \mathrm{~cm}$ & FSO & 13 months & $\begin{array}{l}\text { Omentum and } \\
\text { Pelvis }\end{array}$ & $\begin{array}{c}\text { Initially no chemo, } 3 \text { lines } \\
\text { chemo }\end{array}$ & $\begin{array}{c}\text { Alive } 98 \\
\text { months }\end{array}$ & Alive \\
\hline 30 & 28 & Ia AGCT & $7 \mathrm{~cm}$ & $\begin{array}{c}\text { Complete } \\
\text { Surgery }\end{array}$ & 75 months & Pelvis & Initially no chemo, 2 lines & $\begin{array}{c}\text { Alive } 75 \\
\text { months }\end{array}$ & Alive \\
\hline 31 & 44 & Ic AGCT & $\begin{array}{c}11 \times 12 \\
\mathrm{~cm}\end{array}$ & $\begin{array}{l}\text { Incomplete } \\
\text { Surgery }\end{array}$ & 23 months & Pelvis & $\begin{array}{c}\text { Initially no chemo, CDDP+ } \\
\text { Ctx, then CDDP + Etop }\end{array}$ & $\begin{array}{c}\text { Alive } 85 \\
\text { months }\end{array}$ & Alive \\
\hline 32 & 54 & IIIc AGCT & $\begin{array}{l}9 \times 10 \\
\mathrm{~cm}\end{array}$ & $\begin{array}{l}\text { Incomplete } \\
\text { Surgery }\end{array}$ & 16 months & Pelvis & $\begin{array}{c}\text { Initially no chemo, CDDP+ } \\
\text { Ctx, then CDDP + Etop } \\
\text { then PVB }\end{array}$ & $\begin{array}{l}\text { LTFU at } 28 \\
\text { months }\end{array}$ & LTFU \\
\hline 33 & 60 & IIIC AGCT & $13 \times 13$ & $\begin{array}{c}\text { Incomplete } \\
\text { Surgery }\end{array}$ & 12 months & Pelvis & $\begin{array}{c}\text { CDDP + CTx, then CDDP + } \\
\text { Etop }\end{array}$ & $\begin{array}{c}\text { Dead at } 27 \\
\text { months }\end{array}$ & Died \\
\hline 34 & 67 & IIC AGCT & $10 \times 10$ & $\begin{array}{l}\text { Incomplete } \\
\text { Surgery }\end{array}$ & 24 months & Pelvis & $\begin{array}{c}\text { CDDP + CTX } 6 \text { cycles, then } \\
\text { CDDP + Etop }\end{array}$ & $\begin{array}{c}\text { Dead at } 33 \\
\text { months }\end{array}$ & Died \\
\hline
\end{tabular}

\section{Details of Chemotherapy in the Patients}

\section{Statistical Analysis}

The collected data was analysed with IBM SPSS statistics software 23.0 Version. To describe about the data descriptive statistics frequency analysis, percentage analysis was used. For survival analysis, the Kaplan-Meyer curve with log-rank method was used for the comparison of groups. In the above statistical tools, the probability value of .05 will be considered as significant level. Kaplan-Meier analysis is one of the best ways to measure the proportion of patients living for a certain amount of time after treatment. The time starting from a defined point to the occurrence of a given event, for example death is called as survival time and the analysis of group data as survival analysis. The effect of an intervention is assessed by measuring the number of patients survived after that intervention over a period of time.

The chance of occurrence of events over a period of time is computed and multiplying these successive probabilities by any earlier computed probabilities will give the final estimated values, which are used for plotting survival curves.

\section{RESULTS}

This is an analysis of the survival rate and the treatment results of Granulosa cell tumour between 1995 and 2015 over a period of 20 years. We have analysed the results of 126 patients, of which 53 patients $(42 \%)$ were premenopausal and 73 patients (58\%) were postmenopausal. Out of the 126 patients, 84 patients had complete surgical staging which constitutes transabdominal hysterectomy and bilateral salpingo-oophorectomy and a staging laparotomy, 35 patients had incomplete or suboptimal surgery, 7 patients had fertility sparing operation. The 67 patients who had complete surgery and early stage disease with no risk factors were on observation. These patients have not had relapse. 7 patients after complete surgical staging had chemotherapy with Cisplatin and Cyclophosphamide. Amongst them 2 patients had recurrence and were given chemo with good response surviving. Out of the 35 patients who had incomplete surgery, 13 patients had adjuvant chemo with Cisplatin and Cyclophosphamide and 22 patients were on observation. Amongst the 22 patients who were on observation 6 patients recurred and were treated with 2 - 3 lines of chemo. Out of the 6 patients, 4 patients are alive, and 2 patients died due to progressive treatment. In the 13 patients who had chemo, one relapsed and died without any $2^{\text {nd }}$ line chemo. 9 patients recurred were given $2^{\text {nd }}$ line chemo with Cisplatin and Etoposide and $3^{\text {rd }}$ line with Cisplatin, Vinblastine and Bleomycin or Bleomycin, Etoposide and Cisplatin. 7 patients had fertility sparing surgery and one of them had adjuvant chemo with no relapse. The 6 patients who did not have adjuvant chemo recurred. Amongst, the 6 patients 1 was lost for follow-up, 3 patients died after $2^{\text {nd }}$ line chemo and 2 patients are alive.

On analysing the chemotherapy details and the pattern of failure, there were few points which were clear. In the 
complete surgery group, those with adjuvant chemo did not relapse. Those who relapsed were treated with chemo and had good response to treatment and survived. Those with incomplete surgery had increased risk of recurrence, especially when the size of the tumour was $>9 \mathrm{~cm}$, when there was tumour spill and when the stage was advanced. In the fertility sparing group also, those with lower stage with chemo did better than those with late stage disease, those without chemo or with increased risk factors.

A dataset of 34 patients is analysed, out of these 19 patients have survived cancer. Out of 34 cases, 10 patients had complete surgery and 15 patients had incomplete surgery. Kaplan-Meier survival analysis results show that cancer was cured by complete surgery followed by chemotherapy wherever high-risk factors were present, whereas the survival rate drastically declined in the cases of incomplete surgery without adjuvant chemotherapy. For patients, stage of cancer, size of the tumour, type of surgery done, tumour spill, histopathology, chemotherapy in positive high-risk parameters, has relatively more effect on survival chance.

\section{Analysis of the Treatment Details of Relapsed Patients}
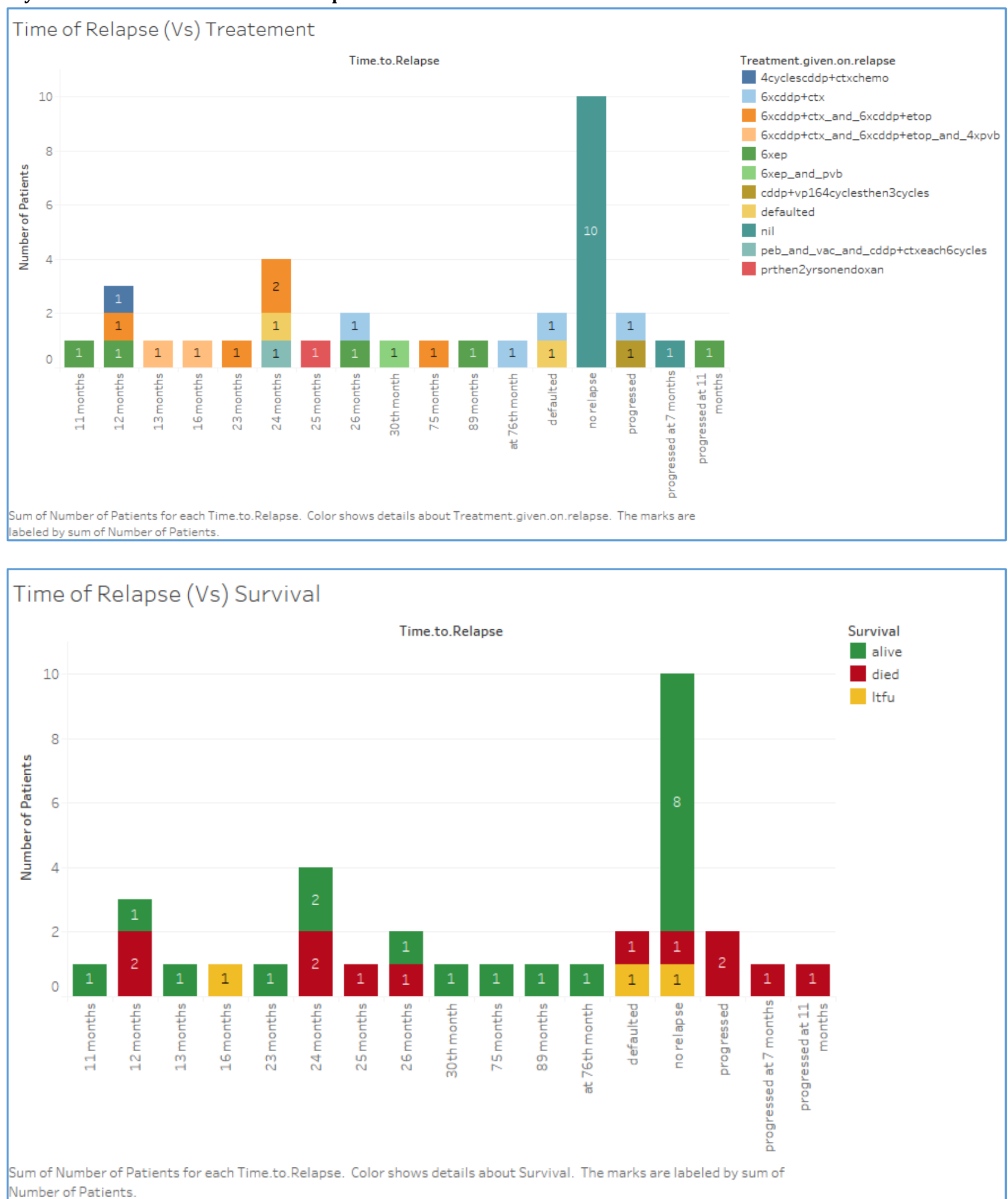

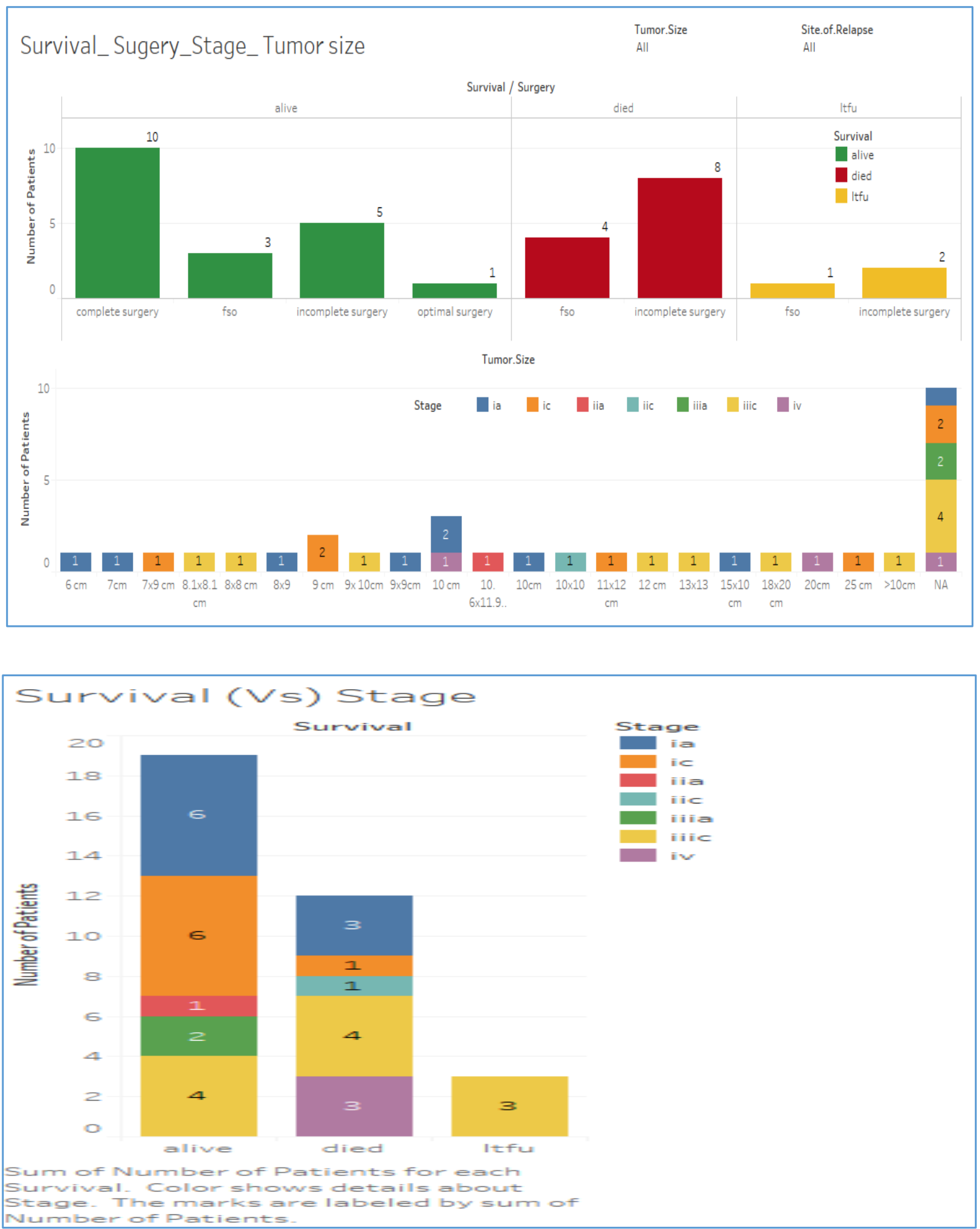


\section{Survival Plot with Respect to Stage}

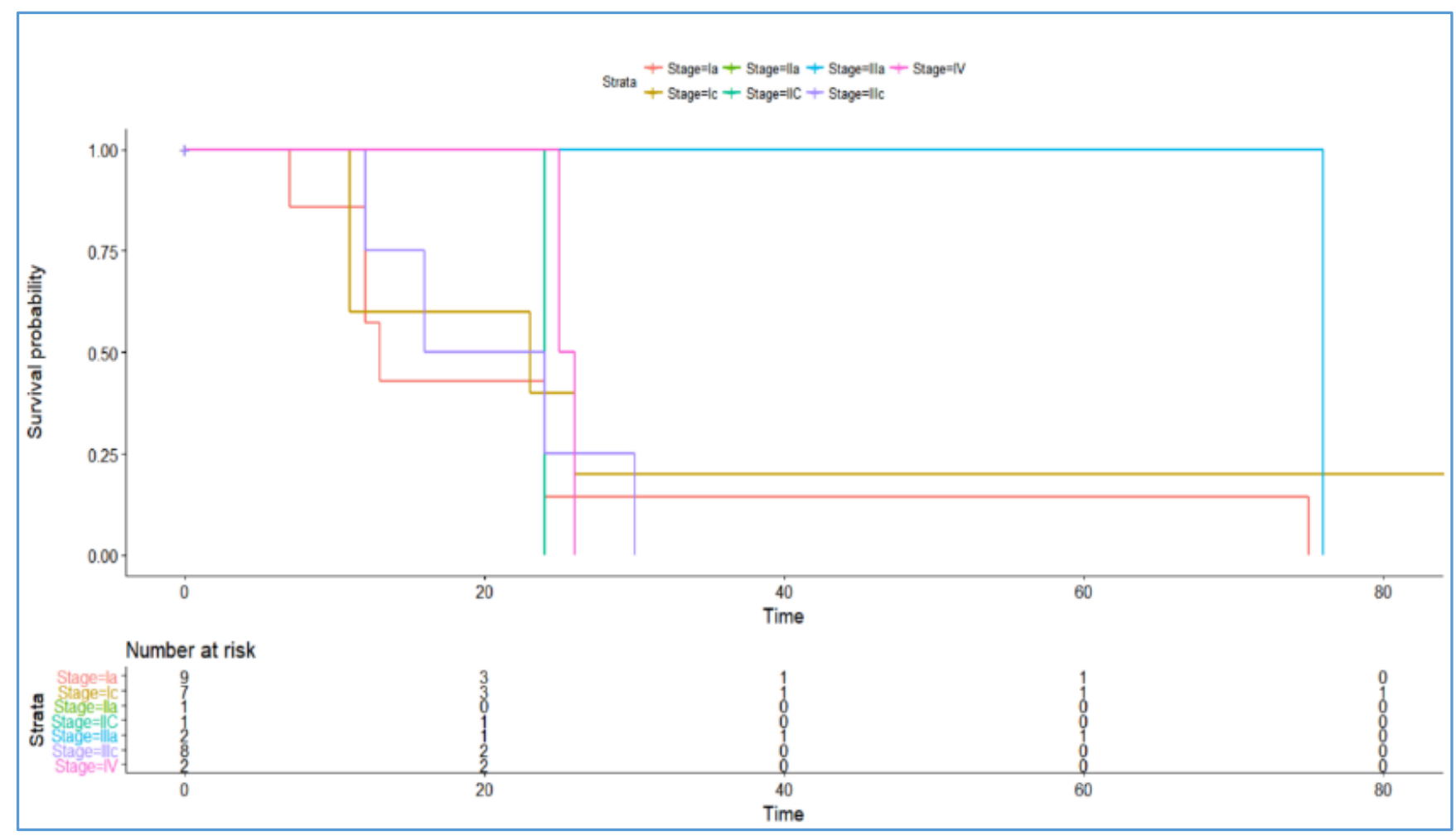

\section{Survival Plot with Respect to Surgery}

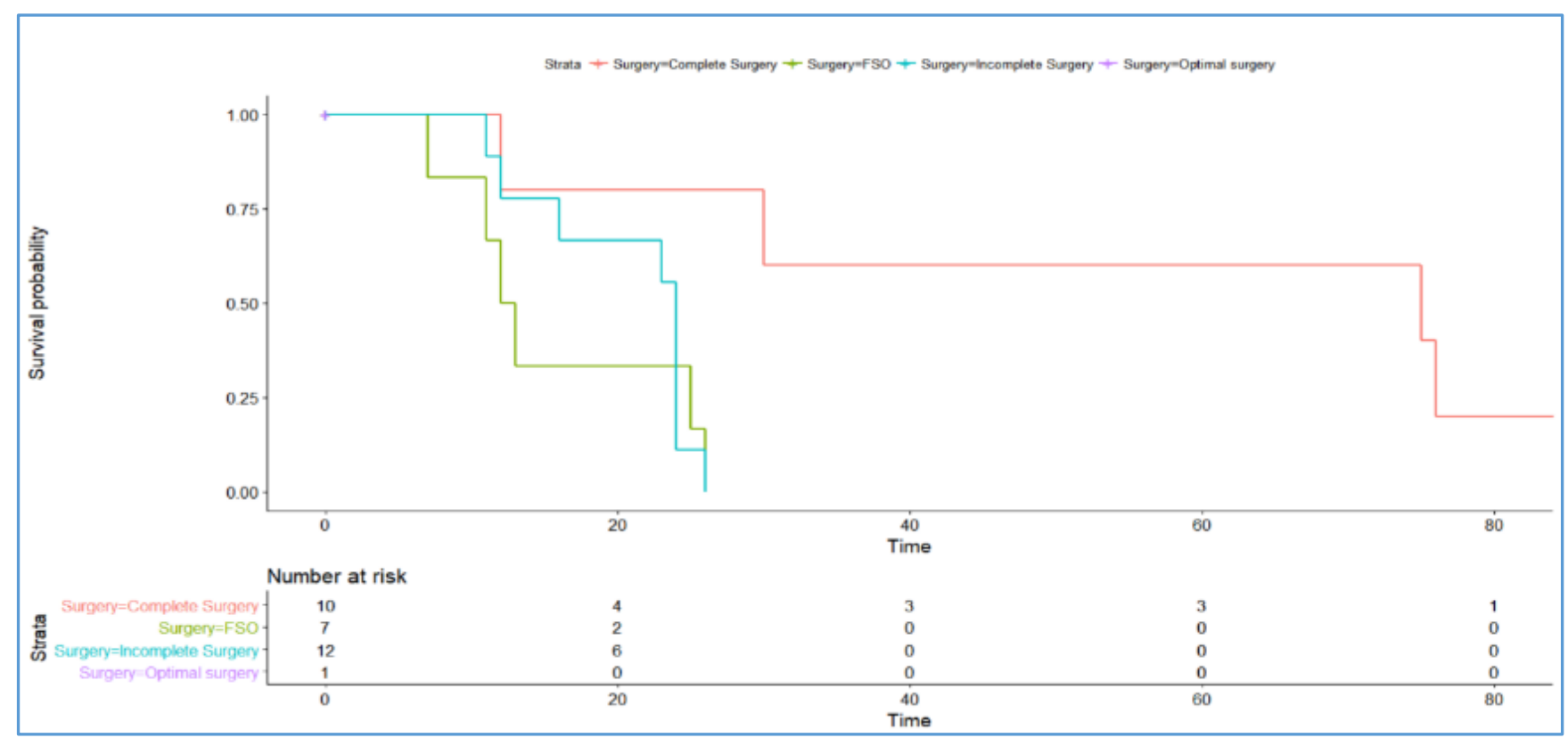




\section{Survival Plot with Respect to Histopathology}

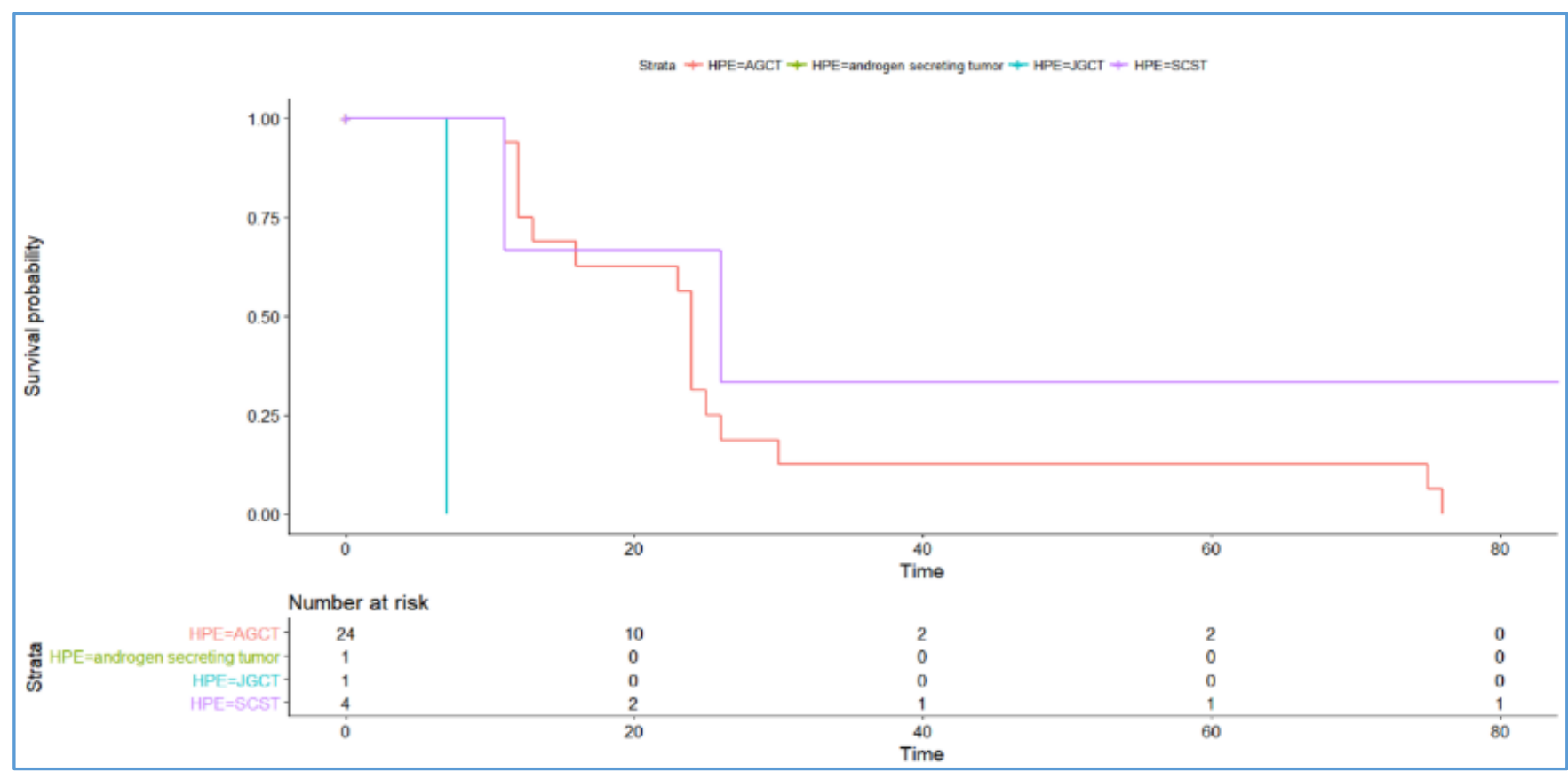

\section{DISCUSSION}

Granulosa cell tumours are a subtype of malignant sex cord stromal tumours. It has two histological types, namely adult $95 \%$ and juvenile 5\%. Adult type occurs in postmenopausal women in the $5^{\text {th }}$ decade with favourable prognosis. Juvenile type occurs in younger age with severe symptoms and signs and increased risk of recurrence implicating poorer prognosis. Hyperoestrogenic symptoms have been reported in a retrospective study of 118 patients with abnormal uterine bleeding, hyperplastic endometrium. It can also produce precocious puberty, mastalgia and galactorrhoea. ${ }^{4}$

Granulosa cell tumours radiologically presents as a solid tumour with cystic component with a median size of $12 \mathrm{~cm} .5$ Diagnosis of granulosa cell tumour is through histopathology. The adult form has 5 subtypes the most common is microfollicular with call exner bodies. The Juvenile form is with macrofollicular with lobulated architecture and few callexner bodies. The common immunohistochemical markers expressed by these cells are alpha inhibin, CD 99, Vimentin; serum tumour markers are inhibin, estradiol, anti-Mullerian hormone. ${ }^{6}$ Serum CA-125 are not of any significance in this tumour variety. ${ }^{7}$ FOXL2 gene mutation has been identified in $97 \%$ of adult granulosa cell tumour and $10 \%$ of juvenile type. The common differential diagnosis with this entity are stromal sarcoma, carcinoid tumour, endometrial cancer and adenocarcinoma. The main modality of treatment here is complete staging laparotomy with transabdominal hysterectomy and bilateral salpingo-oophorectomy with pelvic and para-aortic lymph node resection. For women who would like to preserve the fertility in stage I unilateral salpingo-oophorectomy with uterine preservation is done. In majority of the cases, where the tumour is limited to one ovary the patients are just kept of close follow-up with observation. In case, the stage is IC (Tumour size $>10-15$ $\mathrm{cm}$ ) or there are high risk features such as tumour rupture or poorly differentiated tumour or advanced stages (Stage III or IV). The outcome is unfavourable, therefore in such cases adjuvant chemotherapy is given. ${ }^{11}$ However, the value-add and the significance of the use of the adjuvant chemo is yet to be validated given the rarity of the disease and the difficulty in conducting randomised trial in such rarity. The recommended chemotherapy options available are Paclitaxel + Carboplatin, Bleomycin + Etoposide + Cisplatin (BEP) Etoposide + Cisplatin (EP), Cyclophosphamide + Doxorubicin + Cisplatin (CAP) and platin alone. ${ }^{10}$

In children with juvenile granulosa cell tumour, the usage of adjuvant chemo yields complete and a long-lasting response which is usually given in Stage Ic with a high mitotic index ( $>20$ per high power field). Long surveillance is recommended in granulosa cell tumour, as these tumours have an indolent course. The median time to relapse ranges from 4 years to 30 years. ${ }^{12}$ The sites of recurrence commonly are pelvis, retroperitoneum and upper abdomen. Local relapse is managed with complete resection when feasible. The other chemo regimens in inoperable tumours or the recurrent tumours would be Docetaxel, Paclitaxel + Ifosfamide, Paclitaxel + Carboplatin and VAC. ${ }^{13}$ The hormonal treatment used are Tamoxifen alone, Megestrol or in combination which does produce sustained long-term clinical response. The investigational agents in relapse cases includes anti-angiogenic therapy, LHRH antagonist and mTOR inhibitors. ${ }^{14}$ Large tumour size $>10 \mathrm{~cm}$ is associated with poor prognosis. In Sehouili's trial, survival was lower with suboptimal surgery or residual tumour or tumour rupture. ${ }^{15,16,17}$

\section{CONCLUSION}

Granulosa cell tumours are known for their rarity. They occur both in premenopausal and postmenopausal women. Patients who had tumour size of $>10 \mathrm{~cm}$ seem to have more recurrence. Juvenile granulosa cell tumour and sex cord stromal tumours have poorer prognosis as compared to adult granulosa tumour. The role of chemotherapy is explicit in operated cases, as adjuvant in high risk group decreasing the recurrence rates. Chemotherapy has a compelling role in locally advanced cases, inoperable cases, metastatic cases, in 
cases with tumour spill or rupture, certain histopathological variants (such as juvenile granulosa cell tumour, yolk sac tumour), tumours $>10 \mathrm{~cm}$. Other factors which do contribute to the prognosis would be age at diagnosis, nuclear atypia, mitotic index, surgical method and presence of residual disease after initial surgery.18,19,20

\section{REFERENCES}

[1] Seagle BL, Ann P, Butler S, et al. Ovarian granulosa cell tumor: A National Cancer Database study. Gynecol Oncol 2017;146(2):285-91.

[2] Calaminus G, Wessalowski R, Harms D, et al. Juvenile granulosa cell tumors of the ovary in children and adolescents: results from 33 patients registered in a prospective cooperative study. Gynecol Oncol 1997;65(3):447-52.

[3] Segal R, DePetrillo AD, Thomas G. Clinical review of adult granulosa cell tumors of the ovary. Gynecol Oncol 1995;56(3):338-44.

[4] Khosla D, Dimri K, Pandey AK, et al. Ovarian granulosa cell tumor: clinical features, treatment, outcome and prognostic factors. N Am J Med Sci 2014;6(3):133-8.

[5] Pautier $\mathrm{P}$, Lhommé $\mathrm{C}$, Culine $\mathrm{S}$, et al. Adult granulosacell tumor of the ovary: a rétrospective study of 45 cases. Int J Gynecol Cancer 1997;7(1):58-65.

[6] Shim SH, Lee SJ, Kim DY, et al. A long-term follow-up study of 91 cases with ovarian granulosa cell tumors. Anticancer Res 2014;34(2):1001-10.

[7] Sekkate S, Kairouani M, Serji B, et al. Ovarian granulosa cell tumors: a retrospective study of 27 cases and a review of the literature. World J Surg Oncol 2013;11(1):142.

[8] D'Angelo E, Mozos A, Nakayama D, et al. Prognostic significance of FOXL2 mutation and mRNA expression in adult and juvenile granulosa cell tumors of the ovary. Modern Pathol 2011;24(10):1360-7.

[9] Gershenson DM. Sex cord-stromal tumors of the ovary: Granulosa-stromal cell tumors. Up To Date. https://www.uptodate.com/contents/sex-cordstromal-tumors-of-the-ovary-granulosa-Cell tumors.
[10] NCCN Guidelines for Patients® | Ovarian Cancer. www.nccn.org/patients/guidelines/ovarian/index.ht $\mathrm{ml}$

[11] Van Meurs HS, Buist MR, Westermann AM, et al. Effectiveness of chemotherapy in measurable granulosa cell tumors: a retrospective study and review of literature. Intl J Gynecol Cancer 2014;24(3):496-505.

[12] Mangili G, Ottolina J, Gadducci A, et al. Long-term follow-up is crucial after treatment for granulosa cell tumours of the ovary. Br J Cancer 2013;109(1):29-34.

[13] Koutroumpa I, Thomakos N, Sotiropoulou M, et al. Clinicopathological prognostic factors for recurrence in adult granulosa cell tumor of the ovary. Gynecol Oncol 2014;133(Suppl 1):84.

[14] Kottarathil VD, Antony MA, Nair IR, et al. Recent advances in granulosa cell tumor ovary: a review. Indian J Surg Oncol 2013;4(1):37-47.

[15] Malmstrom H, Hogberg T, Risberg B, et al. Granulosa cell tumors of the ovary: prognostic factors and outcome. Gynecol Oncol 1994;52(1):50-5.

[16] Zhang M, Cheung MK, Shin JY, et al. Prognostic factors responsible for survival in sex cord stromal tumors of the ovary- an analysis of 376 women. Gynecol Oncolo 2007;104(2):396-400.

[17] Sehouli J, Drescher FS, Mustea A, et al. Granulosa cell tumor of the ovary: 10 years follow-up data of 65 patients. Anticancer Res 2004;24(2C):1223-30.

[18] Bjorkholm E, Silfversward C. Prognostic factors in granulosa cell tumors. Gynecol Oncol 1981;11(3):261 74.

[19] Ayhan A, Salman MC, Velipasaoglu M, et al. Prognostic factors in adult granulosa cell tumors of the ovary: a retrospective analysis of 80 cases. J Gynecol Oncol 2009;20(3):158-63.

[20] Lauszus FF, Peterson AC. Granulosa cell tumor of the ovary: a population-based study of 37 women with stage I disease. Gynecol Oncol 2001;81(3):456-60. 